\title{
Note to the Reader
}

\section{Abbreviations}

The following abbreviations are used in parentheses in the text for citations from the works most commonly quoted. Full bibliographical details will be found on the first occasion when each one is referred to.

JHY Li Ruzhen, Jing hua yuan.

GCSD Zhang Yingchang, ed., Guochao shiduo = Qing shi duo.

RHC Ping Jinya, Renhai chao.

XSEN Hao Ran, Xisha er-nü.

NZ Sima Zhongyuan, Niezhong.

SF Li Ang, Shafu. Lucheng gushi.

FHR Yu Guanzhong, Fen-he ren.

FFSZ Yuan Ze'nan, Fanfu suzi.

\section{Quotation Marks}

In the main text, double quotation marks ("/") are only used for the demarcation of direct citations from an identified author or work, and to show direct speech. Single quotation marks ('/') are used for all other purposes, such as to indicate the discussion of, definition of, or literal reference to the enclosed word or phrase, or else the use of this word or phrase in a special or unusual sense, either by the present author or by a speaker being quioted. In the notes, double quotation marks also enclose the titles of journal ar- 
ticles, and the usual convention of alternating double and single quotation marks when one quotation is embedded in another is likewise generally observed. Concluding double quotation marks enclose phrase- or clause-terminal punctuation (such as commas and periods); single quotation marks do not, unless the punctuation is itself part of the word or phrase being referred to, or unless the single quotation marks are marking an embedded quote. 
Les spécialistes d'histoire culturelle savent aujourd'hui étudier les institutions, les objets, les pratiques mais ils n'osent aborder les dispositifs affectifs dont seul la connaissance conférerait un sens à leurs patientes et fructueueses recherches. C'est qu'en ce domaine, le statut du document et la validité de la preuve posent des problèmes d'une particulière acuité.... Tout compte fait, le plus grave à mes yeux n'en demeure pas moins l'anachronisme psychologique. Le pire, c'est la tranquille, abusive et aveugle certitude de la compréhension du passé.... Répérer les mécanismes de l'émotion nouvelle ... constitue l'indispensable. Il n'est pas d'autre moyen de connaître les hommes du passé que de tenter ... de vivre leurs émotions.

-Alain Corbin, Foreword, Le territoire du vide: L'Occident et le désir du rivage, 1750-1840 (Paris: Flammarion, 1988)

Today, specialists in cultural history know how to study institutions, objects, and practices, but they lack the knowledge to tackle those affective dispositions the knowledge of which alone can give a meaning to their patient and fruitful investigations. The reason for this is that, in this domain, the status of documents and the validity of proofs present especially difficult problems.... All things considered, to my way of thinking, the most serious failing nonetheless continues to be psychological anachronism. Worst is the calm, unwarranted, and blind certainty that one understands the past.... Indentifying the mechanisms of new emotions ... constitutes the indispensable element. There is no other way of knowing those who lived in the past except ... by trying to live their emotions oneself. 
